\title{
ECONOMIC VOTING IN THE PHILIPPINES
}

Amelia L. BELLO ${ }^{1 *}$

Received: August 2021 | Accepted: November 2021 | Published: December 2021

Please cite this paper as: Bello,A. (2021) Economic voting in the Philippines, Holistica Journal of

Business and Public Administration, Vol. 12, Iss. 3, pp.1-12

\begin{abstract}
The article wanted to find out if elections in the Philippines are economically motivated. Using 2019 gubernatorial election results, a logit model with inflation rate, unemployment rate, provincial revenue, and poverty incidence for the economic variables and party affiliation with the President and membership in a political family as the political variables was tested to explain the probability of an incumbent governor to be re-elected. The marginal effects tell us that a change in the unemployment rate decreases the predicted probability of a governor being reelected but interestingly, a change in the poverty incidence rates has the opposite effect.

Keywords: economic voting; incumbent-oriented hypothesis; restrospective
\end{abstract}

\section{Introduction}

In 2022, the Philippines will hold national and local elections. While there have been several studies on vote buying, there is very limited work on the role of economic and political factors on incumbent re-election in the Philippines. Gelomina (2013) tested the relevance of the incumbent-oriented hypothesis in the local elections using crosssectional data. Specifically, the study looked at the sociotropic voting model which assumes that the electorate is retrospective with respect to aggregate economic conditions.

The incumbent -oriented hypothesis views the electorate as retrospective, i.e., they pay attention to the performance of the incumbent and is more concerned with policy results rather than the policy itself. The decision rule posited by the hypothesis is that the electorate will support the incumbent if something goods occurs and will blame the incumbent when something bad happens.

This study is almost a replicate of Gelomina's paper which was done using the 2010 results. In 2010, the country chose a new president as well as new senators and

${ }^{1}$ Department of Economics, College of Economics and Management, University of the Philippines Los Baños , Philippines, albello@up.edu.ph 
governors. In 2013, 2016, and 2019, local elections were held but in 2016, a presidential election was likewise conducted. This study will use the results of the 2019 gubernatorial elections. Like Gelomina, the main objective is to analyse the factors, both economic and political factors, that affect electoral outcomes at the provincial level.

\section{Incumbent-oriented Hypothesis and Sociotropic Voting}

This section looks deeper into the relationship between the economy and elections. Economic voting occurs when election outcomes are affected by economic conditions. Since individuals are assumed to be utility-maximisers, they will gather information that will help them analyse and make their decision, and in the process, maximising their utility.

What exactly constitutes economic voting? Lewis- Beck and Stegmaier (2000) say that there are three dimensions: target, time, and context. The object of the evaluation is the target. The time dimension asks whether the vote is looking at the economic past or the economic future. The last dimension considers whether the target is explicitly linked to the policy.

An incumbent candidate is seen as having an advantage over the opposing candidate. The incumbent can use the machinery of the position to put in place and maybe manipulate the policies and programs /projects to be implemented. Given that the electorate also tend to base their decisions on their assessment of the incumbent, we may say that the electorate is retrospective.

Cruz, Keefer and Labonnes (2015) show that the existence and importance of a large public spending program, the types of services the program could finance, and candidate priorities and promises regarding the program led to significant changes in voter knowledge about incumbents and also led candidates to spend more resources on vote buying in the May 2013 Philippine elections. This is because the incumbent has an information advantage and information shocks that raise voters' thresholds for incumbent performance shortly before an election oblige incumbents to do more to increase voter welfare than they anticipated.

Earlier, Harrington (1993) has shown that the less uncertain are voters as to which policy is best, the more likely is a politician to manipulate policy for reelection purposes. Manipulation takes the form of implementing policies that are more likely to be wellreceived rather than a policy that increases welfare.

Kramer's 1971 paper is the seminal work which successfully linked national economic conditions with local electoral outcomes. Economic upturns help the incumbent, but economic downturns hurt the incumbent. Subsequent studies (Cohen and King 2005, Ebeid and Rodden 2006) assumed that governors are held accountable for the state of their states with the electorate giving greater support to the incumbent when the election is preceded by a period of good economic conditions. Kiewet (1983) called this the incumbent-oriented hypothesis where voting in response to economic issues is retrospective and based on the results of economic policies. 
Meanwhile, sociotropic voting asserts that it is the perceptions of the economic conditions that influence the behaviour of the electorate. With sociotropic voting, economic conditions have a strong impact over an individual's voting decisions. An electorate who believes that the economy is doing well will tend to support the incumbent but support the opposition when the economy is perceived to have worsened. In contrast, pocketbook voting on the other hand, suggests that the electorate's decision is in response to personally experienced conditions.

Kramer's 1971 work looked at the relationship between real per capita income, inflation, unemployment, and electoral outcomes and found that except for unemployment, the other two economic factors have a significant correlation with electoral outcomes. Changes in real per capita income also have a strong effect on the total votes received by the incumbent. Sharma (2010) however argued that Kramer (1971) has failed to establish the relationship between local economic conditions and local electoral outcomes. Thus, studies which followed Kramer (1971) developed models to determine the impacts of local economic conditions on the electorate's choice in local elections.

Svoboda (1995) found that retrospective evaluations of governors have significant effects on the choice of voters. In an election with an incumbent candidate, the key determinant was the incumbent's past performance while in an election without an incumbent, the key determinant was presidential evaluations. Cohen and King (2004, 2005) suggested that the electorate evaluate their governors by comparing local and national economic conditions and included presidential popularity, shared party affiliation with the president, party identification, and length of time in office as variables. According to Cohen and King's papers (2004, 2005), presidential popularity positively affects gubernatorial approval, but partisan affiliation can become a liability also. The effect of length of tenure was curvilinear; the longer the governor stays in office, the lower the approval up to a point when approval begins to rise with tenure.

\section{The Variables and Methodology}

There are two sets of variables that was used in the study: economic and political. The explanatory economics variables are the inflation rate, poverty incidence, provincial revenue, and unemployment rate while the political variables are party affiliation and membership in a political family. Data for the first three economic variables are at the provincial level but unfortunately, unemployment rates available are only at the regional level. Revenue includes total transfers, assistance, and subsidy and other non-operating income. The bulk of revenue however is current operating revenue. Tax revenue, other national taxes, internal revenue allotment (IRA), service and business income, shares, grants, donations, and gains make up total revenue from current operations.

The Rappler Philippines 2019 article defined a political family as a set of at least two politicians who are related to each other up to the 3rd degree of consanguinity (by blood) or affinity (by marriage) serving at the same time in a 3-year term, usually in one 
HOLISTICA Vol 12, Issue 3, 2021, pp.1-12

locality. This is to distinguish it from a political dynasty, or families who have served across several terms, even in various localities. Thus, political clans whose members lost in 2019, or have only one remaining family member in office after the polls, despite ruling a locality for a long time are excluded. The dependent variable is Incumbent reelection of the governor.

Table 1 Definition of Variables

\begin{tabular}{|c|c|c|}
\hline Variable & Definition & Source \\
\hline $\begin{array}{l}\text { Incumbent Re- } \\
\text { election } 2019\end{array}$ & $\begin{array}{c}1=\text { if the } \\
\text { elected } \\
\text { governor is } \\
\text { an } \\
\text { incumbent, } \\
0 \text { otherwise }\end{array}$ & https://comelec.gov.ph/?r=2019NLE/ElectionResults_ \\
\hline Inflation & $\begin{array}{l}\text { Change in } \\
\text { the CPI } \\
\text { from } 2018 \text { - } \\
2019\end{array}$ & https://psa.gov.ph/price-indices/cpi-ir? \\
\hline \multirow[t]{2}{*}{$\begin{array}{l}\text { Poverty } \\
\text { Incidence }\end{array}$} & $\begin{array}{c}\text { Poverty } \\
\text { incidence } \\
\text { rate in } 2018\end{array}$ & https://psa.gov.ph/poverty-press-releases \\
\hline & $\begin{array}{l}\text { 2019, in } \\
P^{\prime} 000\end{array}$ & \\
\hline \multirow[t]{2}{*}{$\begin{array}{l}\text { Provincial } \\
\text { Revenue }\end{array}$} & & $\begin{array}{l}\text { file:///C:/Users/Amelia\%20L.\%20Bello/Downloads/ } \\
\text { 2019_AFR_Local_Govt_Volume_I\%20(1).pdf }\end{array}$ \\
\hline & $\begin{array}{l}\text { Regional, } \\
2019 \text {, in \% }\end{array}$ & \\
\hline $\begin{array}{l}\text { Unemployment } \\
\text { Rate }\end{array}$ & & http://www.ble.dole.gov.ph/downloads/Jobsfit\%20publications \\
\hline \multirow[t]{2}{*}{ Party Affiliation } & $\begin{array}{c}\text { 1= same } \\
\text { political } \\
\text { party as the } \\
\text { President }\end{array}$ & https://comelec.gov.ph/?r=2019NLE/ElectionResults_ \\
\hline & $\begin{array}{c}1=\text { if } \\
\text { member, } 0\end{array}$ & \\
\hline
\end{tabular}


otherwise

Membership in

Political Family

https://www.rappler.com/newsbreak/in-depth/map-majorpolitical-families-philippines-after-elections-2019

Source: Author' synthesis, 2021.

This study differed from Gelomina in two aspects: the use of regional data for unemployment and in the definition of membership in a political family. Gelomina used membership in a political dynasty. An elected governor was considered part of a political dynasty if he/she has a close relative (parents, children, siblings, sibling's spouse, uncle, aunt, first cousins, and grandparents) who was elected previously or holds an elective position at the provincial level. In addition, Gelomina also had length of tenure as an independent variable. However, this variable was not used in this study because of unavailable data.

Gelomina's study covered 78 provinces. However, due to changes in political boundaries nine years later and unavailability of data, this study covers only 75 provinces.

The probit equations in Gelomina are as follows:

Eq. (1) Incumbent Re-election $=\alpha+\beta_{i} X_{i}+\lambda_{i} Y_{i}+\varepsilon$

where $X_{1}$ is a vector of economic variables and $Y_{i}$ is a vector of political variables.

Three probit specifications - one using the 2010 levels, a second using percentage changes and a third using absolute changes in the variables were used.

On the other hand, the basic logit equation specified for this paper is:

Eq. (2) Incumbent Reelection $=\alpha+\beta_{i} X_{i}+\lambda_{i} Y_{i}+\varepsilon$

where $X$ is a vector of the economic variables (inflation rate, poverty incidence rate, provincial revenue, and unemployment rate) and $Y$ is a vector of political variables (party affiliation and membership in a political family).

A variant of Equation 2 is also specified; the independent economic variables are now measured as changes, i.e., changes in the inflation rate, changes in poverty incidence rate, changes in provincial revenue, and changes in the unemployment rate.

For each of the two variants, there were also three runs. The first run only had the economic variables as regressors, the second run had both economic and political variables as regressors and the third featured an interaction between the two political variables. Thus, a total of 6 runs were done. 
HOLISTICA Vol 12, Issue 3, 2021, pp.1-12

\section{Results}

Table 2 presents the summary of the local election results.

Table 22019 Gubernatorial Election Results

\begin{tabular}{lc}
\hline Details & Number \\
\hline How many incumbents were reelected? & 35 \\
How many new governors were elected? & 40 \\
How many of the 75 governors belong to the same & 39 \\
party of the President? & \\
How many of the 75 governors do not share party affiliation \\
with the President? & 36 \\
How many are members of a family dynasty? & 55 \\
How many are not members of a family dynasty? & 20 \\
\end{tabular}

Source: Author' synthesis, 2021.

Meanwhile Table 3 presents the cross tabulations of the election results. Despite a decrease in inflation, 34 provinces decided to elect a new governor and an equal number voted for the incumbent. Almost the same can be said for the case of poverty incidence where despite the decrease in poverty incidence in their locales, 37 provinces elected a new governor. The number of new governors who were elected following an increase in the province's revenue was 36 while 31 were reelected. Finally, with respect to unemployment, despite the increase in the unemployment rate, 33 incumbent governors were elected.

Table 3 Cross Tabulations

\begin{tabular}{|c|c|c|}
\hline & $\begin{array}{l}\text { Decrease in Inflation } \\
\text { Rate }\end{array}$ & $\begin{array}{l}\text { Increase in inflation } \\
\text { Rate }\end{array}$ \\
\hline Incumbent & 34 & 1 \\
\hline \multirow[t]{3}{*}{ New } & 34 & 6 \\
\hline & 58 & 7 \\
\hline & $\begin{array}{l}\text { Decrease in Poverty } \\
\text { Incidence }\end{array}$ & $\begin{array}{l}\text { Increase in Poverty } \\
\text { Incidence }\end{array}$ \\
\hline Incumbent & 31 & 4 \\
\hline \multirow[t]{2}{*}{ New } & 37 & 3 \\
\hline & 68 & 7 \\
\hline
\end{tabular}




\begin{tabular}{|c|c|c|}
\hline & Decrease in Revenue & Increase in Revenue \\
\hline Incumbent & 4 & 31 \\
\hline \multirow[t]{3}{*}{ New } & 4 & 36 \\
\hline & 8 & 67 \\
\hline & $\begin{array}{c}\text { Decrease in } \\
\text { Unemployment }\end{array}$ & $\begin{array}{c}\text { Increase in } \\
\text { Unemployment }\end{array}$ \\
\hline Incumbent & 2 & 33 \\
\hline \multirow[t]{2}{*}{ New } & 2 & 38 \\
\hline & 4 & 71 \\
\hline
\end{tabular}

Source: Author' synthesis, 2021.

Overall, there is weak to moderate linear correlation among the variables, whether they be in level form, measured in changes or even with the interaction term. At the level form, poverty incidence and provincial revenue have a correlation coefficient of -0.34 followed by inflation and family dynasty at -0.31 and poverty incidence and unemployment at -0.30 . Measured in changes, the strongest correlation at -0.28 is between changes in unemployment and changes in provincial revenue. When the interaction term is introduced, the interaction term (incumbent * party affiliation) had a -0.28 correlation with inflation.

Runs 1-3 were not significant and had no significant variables. In Runs 4 and 5, change in poverty incidence was significant at $10 \%$ but in Runs $4-6$, change in unemployment was significant at $5 \%$.

Run 4, however was the only model whose LR chi square is statistically significant at $10 \%$ level. Note that Run 4 only had economic variables, i.e., changes in the economic variables, Run 5 incorporates the political variables with changes in the economic variables while Run 6 had the interaction term between the political variables.

For Run 4, the marginal effects tell us that a change in the unemployment rate decreases the predicted probability of a governor being reelected but interestingly, a change in the poverty incidence rates has the opposite effect. 
HOLISTICA Vol 12, Issue 3, 2021, pp.1-12

Table 4 Logit Results

\begin{tabular}{|c|c|c|c|c|c|c|}
\hline 7 & (1) & (2) & (3) & (4) & (5) & $(6)$ \\
\hline VARIABLES & Run 1 & Run 2 & Run 3 & Run 4 & Run 5 & Run 6 \\
\hline $0 b . b \# 1 . c$ & & & $\begin{array}{c}0.230 \\
(0.826)\end{array}$ & & & $\begin{array}{l}-0.298 \\
(0.860)\end{array}$ \\
\hline $1 . b \# 0 \mathrm{~b} . \mathrm{c}$ & & & $\begin{array}{l}-0.717 \\
(0.996)\end{array}$ & & & $\begin{array}{l}-0.881 \\
(1.058)\end{array}$ \\
\hline 1.b\#1.c & & & $\begin{array}{c}0.631 \\
(0.854)\end{array}$ & & & $\begin{array}{c}0.187 \\
(0.888)\end{array}$ \\
\hline Inflation & $\begin{array}{l}-0.0457 \\
(0.199)\end{array}$ & $\begin{array}{l}0.0536 \\
(0.217)\end{array}$ & $\begin{array}{l}0.0424 \\
(0.218)\end{array}$ & & & \\
\hline Poverty Incidence & $\begin{array}{c}-0.0153 \\
(0.0310)\end{array}$ & $\begin{array}{c}-0.0157 \\
(0.0318)\end{array}$ & $\begin{array}{c}-0.0124 \\
(0.0321)\end{array}$ & & & \\
\hline Prov Revenue & $\begin{array}{c}1.07 \mathrm{e}-07 \\
(2.00 \mathrm{e}-07)\end{array}$ & $\begin{array}{c}9.95 \mathrm{e}-08 \\
(2.03 \mathrm{e}-07)\end{array}$ & $\begin{array}{c}1.23 \mathrm{e}-07 \\
(2.06 \mathrm{e}-07)\end{array}$ & & & \\
\hline Unemployment & $\begin{array}{c}-0.2479462 \\
(0.204)\end{array}$ & $\begin{array}{c}-0.279066 \\
4 \\
(0.211)\end{array}$ & $\begin{array}{c}-0.2747323 \\
(0.212)\end{array}$ & & & \\
\hline 1.b & & $\begin{array}{c}0.136 \\
(0.495)\end{array}$ & & & $\begin{array}{c}0.147 \\
(0.531)\end{array}$ & \\
\hline 1.c & & $\begin{array}{c}0.829 \\
(0.581)\end{array}$ & & & $\begin{array}{c}0.405 \\
(0.606)\end{array}$ & \\
\hline Change in Inflation & & & & $\begin{array}{l}-0.171 \\
(0.133)\end{array}$ & $\begin{array}{l}-0.142 \\
(0.143)\end{array}$ & $\begin{array}{l}-0.137 \\
(0.144)\end{array}$ \\
\hline Change in $\mathrm{Poy}_{n}$ Inc & & & & $\begin{array}{l}0.0515657^{*} \\
(0.0305991)\end{array}$ & $\begin{array}{l}0.0510678 * \\
(0.0308926)\end{array}$ & $\begin{array}{c}0.0477172 \\
(0.0309608)\end{array}$ \\
\hline Change in Revenue & & & & $\begin{array}{l}-7.86 \mathrm{e}-07 \\
(5.91 \mathrm{e}-07)\end{array}$ & $\begin{array}{l}-6.93 \mathrm{e}-07 \\
(6.12 \mathrm{e}-07)\end{array}$ & $\begin{array}{l}-6.63 \mathrm{e}-07 \\
(6.16 \mathrm{e}-07)\end{array}$ \\
\hline Change in Unemp & & & & $\begin{array}{c}-0.535^{* *} \\
(0.255)\end{array}$ & $\begin{array}{c}-0.533^{* *} \\
(0.264)\end{array}$ & $\begin{array}{c}-0.575^{* *} \\
(0.270)\end{array}$ \\
\hline Constant & $\begin{array}{c}1.567 \\
(1.648) \\
\end{array}$ & $\begin{array}{c}0.852 \\
(1.789) \\
\end{array}$ & $\begin{array}{c}1.211 \\
(1.829) \\
\end{array}$ & $\begin{array}{c}0.669 \\
(0.652) \\
\end{array}$ & $\begin{array}{c}0.349 \\
(0.798) \\
\end{array}$ & $\begin{array}{c}0.920 \\
(0.950)\end{array}$ \\
\hline Observations & 75 & 75 & 75 & 75 & 75 & 75 \\
\hline LR chi sq & 1.828 & 3.945 & 4.943 & 8.842 & 9.340 & 10.65 \\
\hline Prob $>$ chi sq & 0.767 & 0.684 & 0.667 & 0.0652 & 0.155 & 0.155 \\
\hline Pseudo $R^{\wedge} \mathbf{2}$ & 0.0176 & 0.0380 & 0.0476 & 0.0851 & 0.0899 & 0.103 \\
\hline Log likelihood & -51.01 & -49.95 & -49.45 & -47.50 & -47.26 & -46.60 \\
\hline \multicolumn{7}{|c|}{$\begin{array}{l}\text { Model 2: econ and political variables } \\
\text { Model 3: econ variables with interacti } \\
\text { Model 4-5: change variables } \\
-\quad \text { Model 4: econ variables } \\
-\quad \text { Model 5: econ and political variables } \\
\text { - Model 6: econ variables with interacti }\end{array}$} \\
\hline
\end{tabular}

Model 4 is the only model whose LR chi square is statistically significant at $10 \%$ level. 
Marginal effects after logit

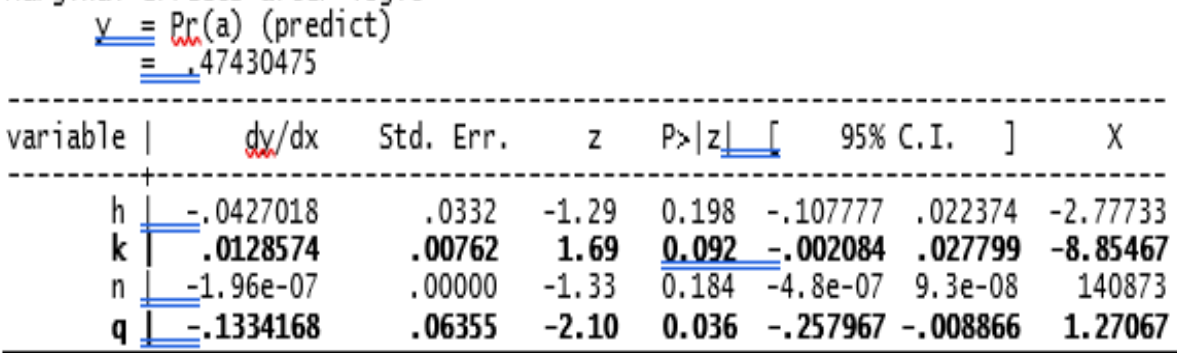

Source: Author' computations and resalts, 2021.

\section{Discussion, Limitations and Conclusions}

Run 4 was the only model whose LR chi square is statistically significant at $10 \%$ level. In Run 4, two of the economic variables were significant in explaining the election results. Unemployment had the expected sign, but poverty incidence did not. In 2016, ending endo contractualization (end of contract) was promised by the incumbent President but it still persists to date. Thus, perhaps the electorate remembered this promise in 2019. Poverty reduction requires a multidimensional approach and projects and programs aimed at reducing the poverty incidence could take years to take a long-run effect. This could probbaby explain the perverse sign of the poverty incidence variable.

Attempts to turn the data set into a panel data by adding 2013 and 2016 results were done. However, getting the political variables for those years proved to be very difficult. Augmenting the study with 2019 micro data was tried but once again, getting data at the individual level was a hard thing. Furthermore, most surveys were done prior to the election and thus the survey results do not necessarily translate into the actual vote. The author however will still pursue the research and explore using other data sets.

Other variables can be incorporated like governance. Hunag (2014) investigated the causal relationship between governance and economic growth in China and Taiwan using the Worlwide Governance Indicators (WGI). The WGI has six dimensions of governance : regulatory quality, political stability, rule of law, control of corruption, government effectiveness and voice and accountability. Likewise, indicators of leadership charisma which was the focus of the paper by Militaru (2013) may be included. Influential leaders use body language and other non-verbal communication methods to inspire and raise the consciousness of their followers as well as to communicate trust and confidence.

In 2014, Rafael Oganesyan at the University of Nevada Las Vegas did his masters thesis entitled "Economic Voting in the Developing World ". The paper argued that the theory of economic voting as we know it, is applicable only to developed countries and not to developing countries. Oganesyan (2014) believes that voters in developing countries 
simultaneously assume both restrospective sociotropic and prospective sociotropic characteristics. In addition, economic voting in the developing world takes place within an asymmetrical framework of punishment and reward. Voters may punish the incumbent more for bad times but reward less during good times.

Likewise, the notion of shared party affiliation as a long-term stable variable is absent due to the infant nature of the political organization and the electoral volatility in the political environments of most developing countries. The infant nature of the political organization has led to weak accountability standards and the inability to cast an economic vote. If the issue of clarity of responsibility (who to assign the blame as well as rewards) is blurred - economic voting might be limited or even nonexistent. Therefore, Oganesyan (2014) argues voters in developing countries may lack the sophistication threshold to hold the incumbent accountable for economic matters. Oganesyan (2014) also notes that there may be inflation and unemployment pain tolerance levels. Inflation and unemployment rates may need to be at certain levels before punishment takes place.

Another paper by Quinlan and Okoliki (2020) says that recently there has been interest in the idea that economic voting is multidimensional but voter's views of economic policy remain unexplored. The latter, which he calls positional economic voting is more likely to hold true for mature democracies.

Voters in developing countries are more often than not, poorly informed about what politicians can do for them and that relatively simple information interventions have a significant effect on this information asymmetry (Cruz, 2015).

Economic and elections are like the warp and weft threads in a fabric. They are said to form a tight weave in the sense that good times keep parties in office but bad times can cast them out. So, when the economic threads anchoring a nation hit a snag or become loose, governments can fail. The relationship between the economy and the electorate in democracies comes from the economic responsiveness of the electors or the individual voters. Thus, it is important to know what voters actually know about the economy since voters act largely on their perceptions of the economy.

\section{Postscript}

During Clinton's 1992 bid for the US presidency, strategist James Carville famously reminded campaign staff, "It's the economy, stupid". Nearly three decades later, P. Moodie (2020) now says that the current pandemic is likely to drive a further shift to economic factors with emphasis on healthcare and how governments have responded to the crisis. Perhaps a new version of Carille's cry would now be, "Don't forget health care". The article by Mkoma, R. and C. Rwekaza (2021) documents how decentralization by devolution enhanced management of the community health fund, overcame the challenges of free fee basic education, among others. 


\section{Acknowledgement}

The author would like to acknowledge the help of Mr. Emman DC Barnedo, MS Statistics student and Ms. Audrey Rose G. Gelomina.

\section{References}

Cohen, J. and J. King. (2005). What Determines a Governor's Popularity? State Politics and Policy

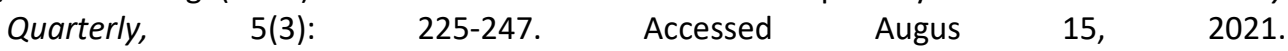
thttps://journals.sagepub.com/doi/10.1177/153244000500500302

Cohen, J. and J. King. (2004). Relative Unemployment and Gubernatorial Popularity, The Journal of Politics, 66(4):1267-1282. Accessed August 15, 2021. https://www.journals.uchicago.edu/doi/abs/10.1111/j.0022-3816.2004.00299.x

Cruz, C. P. Keeper and J. Labonnes. (2015). Incumbent Advantage, Voter Information and Vote Buying. Accessed August 15, 2021. https://publications.iadb.org/en/publication/12499/incumbent-advantage-voterinformation-and-vote-buying

Ebeid, M. and J. Rodden. (2006). Economic Geography and Economic Voting: Evidence From the US States. British Journal of Political Science, 36 (3): 527-547. Accessed August 15, 2021. https://www.cambridge.org/core/journals/british-journal-of-politicalscience/article/economic-geography-and-economic-voting-evidence-from-the-usstates/7153FA68E2BEC697951F54A24B151499

Gelomina, A. (2013). The Significance of the Economy and Politics on Incumbent Re-election in the Philippines. Unpublished Thesis. University of the Philippines Los Banos.

Harrington Jr., J. (1993). Economic Policy, Economic Performance and Elections. The American Economic Review. Vol 83 No1 27-42. Accessed August 15, 2021. https://ideas.repec.org/a/aea/aecrev/v83y1993i1p27-42.html

Hunag, C. (2014).Governance and Economic Growth Nexus in China and Taiwan: A Frequecny Domain Approach. Holistica Journal of Business and Public Administration, 5 (2) : 9-20. Accessed November 9, 2021. https://holisticajournal.ro/history

Kiewet, R. (1983). Macroeconomics and micropolitics. Chicago: University of Chicago Press.

Kramer, G. (1971). Short-Term Fluctuations in U.S. Voting Behavior, The American Political Science Review, 65(1): 131-143. Accessed August 15, 2021. https://econpapers.repec.org/article/cupapsrev/v_3a65_3ay_3a1971_3ai_3a01_3ap_3a1 31-143_5f30.htm

Lewis- Beck, M. and M. Stegmaier. (2000). Economic Determinants of Electoral Outcomes. Annual Review of Political Science 3: 183-219. Accessed August 15, 2021. https://www.annualreviews.org/doi/abs/10.1146/annurev.polisci.3.1.183

Militaru, M. (2013). Charismatic Leadership and Non-Verbal Communication. Holistica Journal of Business and Public Administration, 4 (2) : 15-20. Accessed November 9, 2021. https://holisticajournal.ro/history 
HOLISTICA Vol 12, Issue 3, 2021, pp.1-12

Moodie, P. (2020). Counting on votes: The economics of elections. Accessed August 15, 2021. https://www.intheblack.com/articles/2020/10/01/economics-of-elections

Mkoma, R. and C. Rwekaza (2021). Decentralization in Tanzania: Perceptible Efficicency and Effectiveness in Management of Country Health Care, Free Education and Public Private Partnership. Holistica Journal of Business and Public Administration, 12 (1) : 57-68. Accessed November 9, 2021. https://holisticajournal.ro/history

Oganesyan, R. (2014). Economic Voting in the Developing World. Unpublished MS Thesis. University of Nevada Las Vegas. Accessed August 15, 2021. https://digitalscholarship.unlv.edu/cgi/viewcontent.cgi?article=3202\&context=thesesdisse rtations

Quinlan, S, and M. Okoliki . (2020). Exploring the neglected dimension of the economic vote: a global analysis of the positional economics thesis. Published online by Cambridge $\begin{array}{llll}\text { University } & \text { Press: Accessed } & 2021 .\end{array}$ https://www.cambridge.org/core/journals/european-political-sciencereview/article/exploring-the-neglected-dimension-of-the-economic-vote-a-globalanalysis-of-the-positional-economics-thesis/7B2EB532D83470D707C647D8FD20D85E

Sharma, M. (2010). A Local Analysis of Regional Differences in Economic Indicators and Electoral Outcomes. Accessed August 15, 2021. http://repository.upenn.edu./curej/125 .

Svoboda, C. (1995). Retrospective Voting in Gubernatorial Elections: 1982 and 1986, Political Research Quarterly, 48 (1): 135-150. Accessed August 15, 2021. https://journals.sagepub.com/doi/10.1177/106591299504800108 